\title{
"Does forensic audit influence fraud control? Evidence from Nigerian deposit money banks"
}

\begin{tabular}{|c|c|}
\hline \multirow{5}{*}{ AUTHORS } & Kehinde Adesina (D https://orcid.org/0000-0002-4995-5540 \\
\hline & Olayinka Erin (D https://orcid.org/0000-0002-9624-6018 \\
\hline & Opeyemi Ajetunmobi iD https://orcid.org/0000-0003-0127-2879 \\
\hline & Simon Ilogho id https://orcid.org/0000-0001-5890-5070 \\
\hline & Osariemen Asiriuwa (D https://orcid.org/0000-0001-9553-8767 \\
\hline ARTICLE INFO & $\begin{array}{l}\text { Kehinde Adesina, Olayinka Erin, Opeyemi Ajetunmobi, Simon llogho and } \\
\text { Osariemen Asiriuwa (2020). Does forensic audit influence fraud control? } \\
\text { Evidence from Nigerian deposit money banks. Banks and Bank Systems, 15(2), } \\
\text { 214-229. doi:10.21511/bbs.15(2).2020.19 }\end{array}$ \\
\hline DOI & http://dx.doi.org/10.21511/bbs.15(2).2020.19 \\
\hline RELEASED ON & Tuesday, 30 June 2020 \\
\hline RECEIVED ON & Monday, 28 October 2019 \\
\hline \multirow[t]{2}{*}{ ACCEPTED ON } & Monday, 23 March 2020 \\
\hline & $($ (c) EY \\
\hline LICENSE & $\begin{array}{l}\text { This work is licensed under a Creative Commons Attribution } 4.0 \text { International } \\
\text { License }\end{array}$ \\
\hline JOURNAL & "Banks and Bank Systems" \\
\hline ISSN PRINT & $1816-7403$ \\
\hline ISSN ONLINE & $1991-7074$ \\
\hline PUBLISHER & LLC "Consulting Publishing Company "Business Perspectives" \\
\hline FOUNDER & LLC "Consulting Publishing Company "Business Perspectives" \\
\hline
\end{tabular}

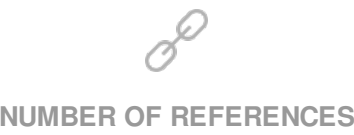

47
NUMBER OF FIGURES

0
NUMBER OF TABLES

15

(C) The author(s) 2023. This publication is an open access article. 


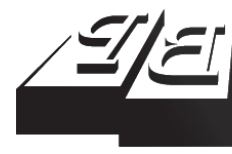

\section{BUSINESS PERSPECTIVES}

()

LLC "CPC "Business Perspectives"

Hryhorii Skovoroda lane, 10, Sumy, 40022, Ukraine

www.businessperspectives.org
Received on: $28^{\text {th }}$ of October, 2019 Accepted on: 23 $3^{\text {rd }}$ of March, 2020 Published on: $30^{\text {th }}$ of June, 2020

(C) Kehinde Adesina, Olayinka Erin, Opeyemi Ajetunmobi, Simon Ilogho, Osariemen Asiriuwa, 2020

Kehinde Adesina, MSc Student, College of Business and Social Sciences, Department of Accounting, Covenant University, Nigeria.

Olayinka Erin, Ph.D., Lecturer, College of Business and Social Sciences, Department of Accounting, Covenan University, Nigeria. (Corresponding author)

Opeyemi Ajetunmobi, Ph.D. Student, Lecturer, College of Business and Socia Sciences, Department of Accounting, Covenant University, Nigeria.

Simon Ilogho, Ph.D. Student, Lecturer, College of Business and Social Sciences, Department of Accounting, Covenant University, Nigeria.

Osariemen Asiriuwa, Ph.D. Student, Lecturer, College of Business and Social Sciences, Department of Accounting, Covenant University, Nigeria.
Kehinde Adesina (Nigeria), Olayinka Erin (Nigeria), Opeyemi Ajetunmobi (Nigeria), Simon Ilogho (Nigeria), Osariemen Asiriuwa (Nigeria)

\section{DOES FORENSIC AUDIT INFLUENCE FRAUD CONTROL? EVIDENCE FROM NIGERIAN DEPOSIT MONEY BANKS}

\begin{abstract}
This study examines the importance of the application of forensic audit in controlling financial frauds that ravage or threaten the soundness and business continuity of Deposit Money Banks (DMBs) in Nigeria. The study used survey design methods, and the primary data were obtained through the administration of structured questionnaire covering seventeen (17) banks out of twenty-two (22) Deposit Money Banks (DMBs) operating in the country, which is $77.3 \%$. In this study, the Ordinary Least Squares (OLS) method was used to analyze and test hypotheses, and the findings showed that the involvement of qualified and experienced forensic auditors would not only contribute to the amelioration of financial frauds in DMBs, but would also lead to much-needed sanity in the banking sector of Nigeria. The study recommends that regulatory agencies, within the limits prescribed by law, mandate all the banks to create a special forensic department, managed by a professional forensic auditor, which will develop and constantly implement effective and efficient internal control, timely prosecution of fraudsters by considering them to be criminals and as a deterrent to others, and work out adequate training and development programs for their staff, especially in fraud control, in order to reduce the number of fraud cases in Nigerian banks.
\end{abstract}

\section{Keywords fraud control, forensic accounting, forensic audit, internal control, Nigerian deposit money banks}

\section{JEL Classification $\quad$ M41, M42}

\section{INTRODUCTION}

Every business organization exists to create wealth for its owners by offering products or services that satisfy effective demand (Efiong, 2012). In an effort to realize the objectives of a business enterprise, all the stakeholder's interests - customers, employees, government, community and so on - must be given due consideration. The organization's vision statement equally provides the future direction the organization is striving to reach. This, therefore, suggests that every business enterprise needs a good leader to create synergy and vision to ensure the attainment of its corporate objective. One of the factors threatening the actualization of the corporate objective of business enterprises globally is fraud (Zhiwei, Lainhart, \& Stabbs, 2014). The incidence of fraudis growing steadily in both private and public sectors globally, although developing countries and their various states to which Nigeria belongs suffer the most pain (Abiola \& Oyewole, 2013). In Nigeria, frauds in banking are on the increase, which contributes to distress and failure of some banks and industries (Nigeria Deposit Insurance Corporation Report, 2016). This poses a threat to the actualization of corporate objectives of a business enterprise.

The notion of fraud, as illustrated by Black's law dictionary (1979), is referred to as an intentional act whereby an individual takes advantage 
over another person through willful deception or suppression of truth. It is a criminal means of misleading with an intention to cheat another party. Dandago (1997), Erin, O. Ogundele, and I. Ogundele (2016) opine that fraud occurs when one or more individuals in an organization, irrespective of position, willfully alter, distort or falsify financial information. Fraud encompasses the engagement of illegal means to access inappropriate or unjust benefits. As earlier emphasized, fraud is a deliberate intention motivated to receive or attract undue advantage. This understanding, therefore, differentiates fraud from error, which in business parlance is referred to as unintentional omissions or disclosures or misstatements. The purpose or intention of error is not to misappropriate the assets of an organization (Madray, 2006).

"Forensic auditing is a rapidly growing field of accounting that describes the engagement that results from actual or anticipated dispute or litigations" (Okoye \& Gbegi, 2013). The word "forensic" means "suitable for use in a court of law", and it is to that standard forensic accountants generally work (Simon, 1996). "Forensic auditing or accounting is an investigative style of accounting used to determine whether an individual or an organization has engaged in any illegal financial activities" (Erin, O. Ogundele, \& I. Ogundele, 2016). A professional forensic accountant may work in the public sector or in the private practice. It has been argued that though forensic accounting is one of the oldest professions, however, its development over the years has spanned to the examinations of several other forms of financial information (Emeh \& Obi, 2013). George (2007) noted that "...forensic accountants are trained professionals whose objectives are to detect and interpret the evidence of normal and abnormal phenomena introduced into accounting records and its resultant effects on financial reporting".

The rise in corporate fraud has forced the corporations and organizations either quoted or not, to look for a possible way of tackling the menace. Nowadays, fraud has become a norm in most organizations and as a result of its widespread occurrence conventional auditing and investigations have become unproductive in its prevention and detection. The fear of fraud is, therefore, the major motivation for employing the services of a forensic auditor to detect and prevent fraud (Gray \& Moussalli, 2006). The introduction of information technology has further unleashed serious threats to business enterprises security with an unprecedented increase in fraud, most especially in the Nigerian banking industry. Despite regulations and audit of the financial statements of the Nigerian banks, the incidences of fraud are still on the increase.

The purpose of this study is to examine the influence of forensic audit on fraud control in Nigerian Money Deposit Banks. The following research questions come to mind:

1. To what extent has the application of forensic audit skills reduced the incidence of frauds in the Nigerian banks?

2. To what extent have the forensic auditor's skills and knowledge improved timely adjudication of financial fraud cases in the law court in Nigeria?

3. What is the significance of the forensic auditor's experience in the detection and prevention of fraud?

4. How does the gender of a forensic auditor influence his/her expert report in ensuring timely execution of financial fraud in the court of law?

\section{LITERATURE REVIEW AND HYPOTHESES DEVELOPMENT}

\subsection{Forensic audit}

The available literature shows that forensic accounting is not a new discipline, but has exist- ed since time immemorial and, as such, cannot be said to be a new profession, although it was not called forensic accounting. The discipline was dated back to the ancient Egyptian scribes who were engaged by Pharaoh to maintain the assets of the king. They were being referred to, at that time, as the 'eyes and ear' of Pharaoh. They performed functions such as calculating, updating and maintenance of the daily accounts. The 
study carried out by Crumbly (2001) confirmed the existence of forensic accounting as far back as the year 1817, when the accountants engaged to examine bankrupt's accounts applied the principles of forensic accounting to testify in the law court. Peloubet (1946) confirmed that Maurice E. Peloubet, a partner in a New York accounting firm, was the first professional to publish the phrase 'forensic accounting' in an article in 1946. He posited that both the public and industrial accountants were and continued to be involved in forensic accounting.

Dhar and Sarkar (2010, p. 3) described forensic auditing as "...the application of accounting concepts and techniques to legal problems. It demands reporting, where accountability of the fraud is established and the report is considered as evidence in the court of law or in administrative proceedings". Forensic accounting is one of the most effective and efficient approaches to reduce and prevent frauds. This is because it provides verifiable evidence tenable in any legal case. As a practical field of endeavor, it addresses areas such as detection of financial falsification or financial statement fraud. The skills of forensic accounting are equally applicable in financial accounting fraud, due diligence, forensic auditing, risk assessment and compliance (Rasey, 2009).

Degboro and Olofinsola (2007) submitted that forensic auditing is all about financial fraud investigation to determine and establish facts in support of legal cases. Apart from the detection and investigation of a crime, it exposes all its attending features and identifies the culprits. According to Onodi, Okafor and Onyali (2015), forensic auditing is a process through which complex financial concerns are clearly, concisely, accurately and unambiguously summarized, interpreted and presented as evidence by an expert witness (forensic auditor) in a court of law. It is construed to mean the application of accounting principles to prove any financial misappropriation in business-related litigation (Okunbor \& Obaretin, 2010). Forensic audit is an aspect of the accounting profession that employs models and methodologies in its investigative processes to produce quality assurance, evidence, and advisory services in support of legal actions. It is relevant in the provision of the necessary accounting data to uncover tax evasion; insolvency, the true value of the asset and inappropriate application of accounting guideline (Dhar \& Sarkar, 2010).

According to Bhasin (2007), “...forensic auditors are trained finance or business experts who professionally analyze, summarize, interpret and present complex financial and business related concerns clearly and understandably". He also reiterated that forensic auditors were involved in activities such as critical analysis and investigation of financial related problems, evidence gathering, the application of information technology techniques in the collection, analysis and presentation of financial matters, generation and presentation of reports on findings, collection and exhibition of evidential documents, assisting jury in legal proceedings, expert witness in courts as well as making use of visual aids to support litigation.

T. Singleton and A. Singleton (2007) stated that forensic accounting can be regarded as one of the oldest professions, and its antecedent was traced to Egypt when the person, who was regarded as a forensic accountant, overseeing the inventories of various products and assets of Pharaoh, was termed 'the eyes and ears' of the king. It can, therefore, be inferred from the above definitions that forensic auditors are basically financial experts employing scientific skills and knowledge to detect frauds and serve as expert witness in legal matters. These legal matters could either be criminal or civil disputes. According to the American Institute of Certified Professional Accountants (AICPA) (2008), "The services of forensic accounting generally involve the application of skills and knowledge in the fields of auditing, accounting, finance, law, quantitative techniques, communication and information technology, research methodology, and investigation to source, collect information, analyze and evaluate evidential matters to serve as evidence tenable at the law court for the prosecution of culprits". It can, therefore, be deduced from the above that a forensic auditor should possess requisite expertise skill to carry out an investigation on financial matters tenable in a law court and could also be called upon to act as an expert witness in the law court on issues relating to financial fraud. 


\subsection{Empirical review}

Oyier (2013), in his research on the impact of forensic accounting services on fraud detection and prevention among commercial banks in Kenya, posited that the need to facilitate fraud detection and prevention led to an increase in demand for the services of professional forensic accountants. The study made use of descriptive research survey design. A total sample of 47 respondents involving 16 commercial banks in Kenya was used for the study. The data sourced from the survey was analyzed using Statistical Package for Social Sciences (SPSS). The findings of the study revealed that the application of forensic accounting skills by banks led to a reduction in financial frauds. On the other hand, the application of forensic accounting skills and techniques enhanced the quality of financial reporting of commercial banks in Kenya. The study concluded that fraudulent expense claims were the most prevalent type of fraud in the Kenyan banking sector.

While the study revealed that banks or various institutions enforced individual responsibility, prosecution of culprits, reinvigoration of internal controls and internal audit checks, retraining and training on emerging trends in frauds, crafting of policy change, mandatory establishment of separate risk and audit fraud departments, and sharing of information with other banks as working strategies to combat frauds, it did not define the extent to which forensic auditors used their professional prowess to invoke the weight of law to sanction the offenders with a view of serving as a deterrent to others, which is the core objective of this research.

Elias (2014) carried out a study on the use of forensic accounting in fraud detection and control in South Africa. The study employed theoretical analysis and literature review using secondary data. The importance of forensic accountants and their roles in minimizing and eliminating fraudulent financial activities were critically examined. The study maintained that forensic accounting expertise, techniques, and principles will enhance timely detection, investigation, and prosecution of perpetrators of financial crimes failing, which would endanger the soundness of the economy. The study emphasized the need for forensic accountants to be adequately trained and the ne- cessity on the part of the Judge to recognize them as experts in the field. The study further opined that in order for forensic accountants to efficiently perform their tasks, they must possess sufficient knowledge and skills in accounting, auditing, verbal and written communication, and information technology.

Ogutu and Ngahu (2016) carried out a study on the application of forensic accounting skills in the mitigation of fraud with particular reference to the practice accounting firms in Nakuru County, Kenya. The study noted that in recent years, forensic accounting has experienced substantial growth and become a vital tool in the detection, prevention, and alleviation of economic crimes globally. They employed two theories, fraud triangle and diamond, for their theoretical review. The research used a descriptive survey research design, and the target population was limited to 25 accounting firms. The researcher made use of a questionnaire as an instrument for data collection. The data were analyzed through the use of frequency distribution tables, bar graphs, and pie charts. The study discovered various areas where forensic accounting could be useful, which include fraud prevention and detection, bankruptcy, insolvency and reorganization, financial statement misrepresentation, economic damage calculations, and family disputes. It also highlighted the attributes a forensic accountant must possess, such as analytical skills, auditing skill, investigative and fraud skills, high ethical standard, confidence, inquisitive mind and skepticism. While the study is limited to practice accounting firms, the researchers do not state how the stated objectives can be achieved but only stated the areas where forensic accountants could be engaged in.

Mukoro, Yamusa, and Faboyede (2013) carried out a study on the role of a forensic accountant in fraud detection and national security. The purpose of the study was to explore the role of forensic accountants in addressing the vicious cycle of crime and corruption ravaging the public sector in Nigeria. The study looked at how the application of forensic accounting skills, such as investigative skills, litigation support services, documentation, and reporting, can be used to fight corruption to a standstill. The Federal Inland Revenue Service (FIRS) was the focus and population for the study 
and the survey research was adopted in carrying out the research. The data used for the study, was basically from the primary source through the administration of the questionnaire. The regression analysis statistical method was used to test hypotheses.

Based on the literature reviewed, the following hypotheses are developed:

H1: Forensic audit has no significant effect on the control of financial frauds in the DMBs in Nigeria.

H2: There is no significant association between the forensic auditor's skills and knowledge and timely adjudication of financial fraud cases in the DMBs in Nigeria.

H3: The experience of a forensic auditor has no significant effect on fraud control in the $D M B s$ in Nigeria.

H4: The gender of a forensic auditor has no significant effect on his/her expert report for timely execution of financial fraud cases in the law court in Nigeria.

\subsection{Theoretical perspectives}

Frauds are perpetrated by individuals and organizations to obtain money, property or services; avoid payment or loss of services; or to secure personal or business advantage. This study examined white-collar crime, fraud diamond, and fraud root theories to exemplify what motivates an individual to engage in fraud.

\subsection{White-collar crime theory}

The term white-collar crime was first coined by a Sociologist, Edwin Sutherland, in 1939. "It literarily means, a crime committed by a person of high repute and social status in his professional calling and also a crime committed by corporations" (Sutherland, 1949). Edwin Sutherland's theory became popular during the address he presented at a symposium organized by the American Sociological Society where he examined two fundamental phenomena, crime and high social status in society. He reiterated that white-collar criminals share the same attributes, characteristics and their modus operandi is typical of street urchins. He used the concept to challenge inappropriate modalities that are often applied when dealing with the similar offense committed by individuals of unequal status.

White-collar offenses include but are not limited to the following: abuses of trust, economic failure fraud, corruption, electronic or high-tech fraud, forgeries and falsification of records, intellectual property theft, misappropriation of funds, tax-related frauds, investment/securities fraud, degradation of environmental laws, public sector fraud, insider privileged information abuses, copyright theft, and insurance-related frauds. It should be noted that the perpetrators of white-collar crimes are known for the engagement of sophisticated apparatus to suppress their fraudulent activities, especially the use of complex transactions, and, as such, they are difficult to track down for prosecution. One of the tested instruments for exposing white-collar criminals is the use of whistleblowers that have been helpful in reporting internal shady transactions. The Nigerian government in recent times has embraced the instrument of whistleblowing to expose some fraudsters who have been arraigned for prosecution.

\subsection{Fraud diamond theory}

Wolf and Hermanson (2004) introduced the fraud diamond model to explain factors that could result in fraud in an organization. The model is an update to fraud triangle, which adds the fourth variable "capabilities" to the three factors earlier mentioned in fraud triangle theory. They were of the opinion that fraud would not have occurred in any organization without internal stimulus or authority to implement it. In this model, four observational traits were identified as leeway for any fraud to be committed. It includes:

1. Authoritative or commanding position of an individual in an organization.

2. The capacity to understand, exploit and circumvent the organization's accounting and internal control system. 
3. The dexterity and confidence that the fraudulent activity will not be detected, or that the perpetrators will not be caught, and if peradventure caught, they will easily get away with it.

4. The capability to deal with the stress created within and to deal with any person that engages in any fraudulent act within an organization.

As a result of the additional element, 'capacity', to the fraud diamond theory that motivates employee or an individual to commit fraud, there is a need for an organization to engage the service of an experienced forensic auditor who has deep understanding of employees' individual differences with a view of assessing the likelihood crystallization of any avoidable behavioral risk that could lead to huge financial loss. In addition, the forensic auditor should be able to assess the adequacy or otherwise of the system of internal control, check and balances, and their practicality in view of the control environment that will proactively minimize risks and losses likely to occur. He will also initiate and design workable programs and strategies for the implementation and monitoring of controls to safeguard the assets of the organization. This will ultimately mitigate or forestall and ameliorate the incidences of frauds and any other atrocities in an organization that could negatively affect its ongoing operations.

\subsection{Fraud root theory}

This study came up with the idea of the fraud root theory to explain the circumstances that could usually lead an individual to commit fraud, which always stems from the environmental factors, in particular, in the black nations of Africa. What motivates an individual to commit frauds in developed nations may not necessarily be the same in developing economies. The rationale for committing fraud in developed nations may be motivated by the perpetrators to prove a point that they are smart and can break into any system irrespective of the complexity of the control system (Chui \& Pike, 2013). Whereas the motivation for an average black man to engage in fraud is borne out of the desire to change his status to a high net-worth individual. These environmental factors are cate- gorized into four groups: (i) poverty, (ii) porous legal system, (iii) culture, custom and tradition, and (iv) the penchant for and holding onto power.

Though all the aforementioned fraud theories are relevant to the study, only fraud diamond theory was adopted. This is based on the premise that the study examined how the accounting and internal control system of Deposit Money Banks (DMBs) could be circumvented to pave way for fraudulent activities. The existence of a fraudster is, therefore, implied in the theory, and to checkmate the consequences of fraud, it is necessary to engage the services of a forensic auditor. This will in effect help identify symptoms of fraud and build an efficient and effective internal control mechanism to prevent and ameliorate fraud.

\section{DATA AND METHODS}

This research work is focused on forensic auditing as a tool for fraud control in the Nigerian Money Deposit Banks (DMBs). The survey research design was employed to obtain the necessary data for making a generalization on the study. This research design was used because it allows a researcher to collect specific information from the target group (bankers) on the subject matter of the study. It makes statistical inferences possible from information collected and describes it more completely (Fox \& Bayat, 2007). It succinctly describes the typical features of a large population and its administration can be carried out from different locations (Uwuigbe, 2011).

\subsection{Sample selection, data collection and analysis}

The population of the study consists of twenty-two (22) Money Deposit Banks (DMBs) operating in the country, including newly licensed regional banks, Suntrust Bank Nigeria Ltd and Providus Bank Plc. Out of these twenty-two (22) banks, ten (10) banks have commercial banking license with international authorization, nine (9) banks have national authorization, two (2) banks have regional authorization, and one (1) non-interest banking with national authorization (Appendix 1). For the purpose of this study, only seventeen (17) banks with international and national authoriza- 
tion, representing $77.3 \%$ of the total commercial banks operating in the country, were considered for the study. This is premised on their branch network with the extensive geographical spread, a large number of employees with multi-lingual and diversities, large customers' base, high volume of transactions and the use of high level of technology.

When distributing the questionnaire, attention was paid to the head offices of the banks, in particular the forensic audit, internal audit, and internal control units. Though banks in Nigeria are deploying forensic auditing skills and tools, they are still functioning as internal auditors. Also, branches within Lagos and Ogun states were randomly selected and targeted the branch Internal Control managers. This is based on the reasons that this crop of personnel is at the vanguard of the implementation of and compliance with policies initiated by the management or regulatory authorities. They also shoulder the responsibilities of detecting and preventing frauds and irregularities. Two hundred (200) copies of the questionnaire were distributed among the seventeen banks, out of which one hundred and ninety-three (193) were returned and processed, representing 96.5\%.

\subsection{Validation and reliability of instruments}

In the context of this study, a research instrument engaged in the collection of data is considered valid when it has the capacity or ability to measure the hypotheses formulated with a view of realizing the study objectives (Trochim, 2009). To ensure the validity of the instrument used, the draft copies of the structured close-ended questionnaire were pilot-tested to determine their level of relevance and appropriateness. The draft copies were approved by the supervisor and distributed to a few selected lecturers and professionals who are erudite researchers in the field of auditing. The questionnaire was modified according to responses received from the reviewers and the final copies were thereafter distributed to the target population for the research.

Again, reliability refers to the degree to which a researcher can confidently rely on the information collected through an instrument of data collec- tion. It implies that the research methodology can only be reliable if the same results were produced consistently by the same participants after repeated trials (Akenbor \& Ironkwe, 2014).

Table 1. Reliability test

\begin{tabular}{c|c}
\hline Cronbach's Alpha & Number of items \\
\hline .795 & 14 \\
\hline
\end{tabular}

The reliability coefficient of the research instrument was assessed using the Cronbach's Alpha coefficient. It measures internal consistency in a group of items combined to form a single scale. It shows how well different items complement each other in terms of determining different aspects of the same variable and its interpretation is similar to the correlation coefficient. A questionnaire as a research instrument is considered reliable or acceptable if the Cronbach's Alpha coefficient is greater than 0.70 (Albrecht, Hill, \& Albrecht, 2006). Therefore, the Cronbach Alpha of $79.5 \%$, as depicted in Table 1, is considered acceptable for this study. It means that the questionnaire administered for this research is adjudged credible in achieving the objectives of this study.

\section{RESULTS AND DISCUSSION}

This section presents the inferential results of the hypotheses tested, and the discussion was made based on the findings.

\subsection{Hypothesis one}

$H_{1}$ : Forensic audit has no significant effect on the control of financial frauds in the Deposit Money Banks (DMBs) in Nigeria.

Tables 2 and 3 show that while the correlation (R) between the independent variables and the dependent variable was 0.649 , the estimated adjusted $\mathrm{R}$ square was 0.409 . This implies that independent variables when taking together accounted for 40.9 percent of the control of financial fraud in DMBs. Further verification using regression ANOVA revealed that forensic audit had a significant effect on the control of financial frauds in the DMBs in Nigeria. Evidence given in Tables 2 and 3, based on the hypothesis tested above, showed that the 
Table 2. Model summary

\begin{tabular}{|c|c|c|c|c|c|c|c|c|c|}
\hline \multirow[b]{2}{*}{ Model } & \multirow[b]{2}{*}{$\mathbf{R}$} & \multirow{2}{*}{$\begin{array}{c}\text { R } \\
\text { square }\end{array}$} & \multirow{2}{*}{$\begin{array}{l}\text { Adjusted } \\
\text { R-squared }\end{array}$} & \multirow{2}{*}{$\begin{array}{l}\text { Std. error of } \\
\text { the estimate }\end{array}$} & \multicolumn{5}{|c|}{ Change statistics } \\
\hline & & & & & R-squared change & F change & df1 & df2 & $\begin{array}{c}\text { Sig. F } \\
\text { change }\end{array}$ \\
\hline 1 & .649a & .422 & .409 & .48960 & .422 & 34.285 & 4 & 188 & .000 \\
\hline
\end{tabular}

Note: a. Predictors: (constant). Forensic audit ensures efficient segregation of duties in this bank to forestall fraud. The practice of forensic accounting helps to mitigate the financial fraud in this bank; Forensic audit guaranteed prompt detection of fraud in this bank; and Forensic audit guarantees the safety of this bank's assets from unauthorized usage.

Table 3. ANOVA

\begin{tabular}{|c|c|c|c|c|c|c|}
\hline & Model & Sum of squares & Df & Mean square & $\mathbf{F}$ & Sig. \\
\hline \multirow{3}{*}{1} & Regression & 32.873 & 4 & 8.218 & 34.285 & $.000^{\mathrm{b}}$ \\
\hline & Residual & 45.065 & 188 & .240 & - & - \\
\hline & Total & 77.938 & 192 & - & - & - \\
\hline
\end{tabular}

Note: a. Dependent variable: Control of financial fraud in DMBs; b. Predictors: (constant). Forensic audit ensures efficient segregation of duties in this bank to forestall fraud. The practice of forensic accounting helps to mitigate the financial fraud in this bank; Forensic audit guaranteed prompt detection of fraud in this bank; and Forensic audit guarantees the safety of this bank's assets from unauthorized usage.

calculated $r$ (0.409) and $F(34.285)$ were greater than the tabulated $r(0.195)$ and $F(2.372)$, given 190 degree of freedom at 0.05 level of significance, thus rejecting the null hypothesis, which states that forensic audit has no significant effect on the control of financial frauds in the DMBs in Nigeria.

To determine the relative importance of the significant predictors, Table 4 shows standardized coefficients. Even though forensic audit guaranteed prompt detection of fraud in DMBs has a small coefficient compared to the practice of forensic accounting, which helps mitigate the financial fraud, forensic audit ensures efficient segregation of duties to forestall fraud and contributes more to the model, since it has a larger absolute standardized coefficient. For most predictors, the values of the partial and part correlations increase sharply from the zero-order correlation. This means, for example, that much of the variance in control of financial fraud in DMBs has been explained by a forensic audit. The tolerance is the percentage of the variance in a given predictor that cannot be explained by the other predictors. Thus, the small tolerances show that $70 \%-90 \%$ of the variance in a given predictor can be explained by the other predictors. When the tolerances are close to 0 , high multicollinearity is observed and the standard error of the regression coefficients will be inflated. A variance inflation factor greater than 10 is usually

Table 4. Coefficients

\begin{tabular}{|c|c|c|c|c|c|c|c|c|c|c|c|}
\hline & \multirow{2}{*}{ Model } & \multicolumn{2}{|c|}{$\begin{array}{c}\text { Unstandardized } \\
\text { coefficients }\end{array}$} & \multirow{2}{*}{$\begin{array}{c}\text { Standardized } \\
\text { coefficients } \\
\text { Beta }\end{array}$} & \multirow{2}{*}{$\mathbf{t}$} & \multirow{2}{*}{ Sig. } & \multicolumn{3}{|c|}{ Correlations } & \multicolumn{2}{|c|}{$\begin{array}{c}\text { Collinearity } \\
\text { statistics }\end{array}$} \\
\hline & & B & $\begin{array}{l}\text { Std. } \\
\text { error }\end{array}$ & & & & $\begin{array}{l}\text { Zero- } \\
\text { order }\end{array}$ & Partial & Part & Tolerance & VIF \\
\hline \multirow{5}{*}{1} & (Constant) & 9.221 & .640 & & 14.413 & .000 & & & & & \\
\hline & $\begin{array}{l}\text { The practice of forensic } \\
\text { accounting helps mitigate } \\
\text { financial fraud in this bank }\end{array}$ & -.036 & .076 & -.027 & -.477 & .634 & -.052 & -.035 & -.026 & .991 & 1.009 \\
\hline & $\begin{array}{l}\text { Forensic audit guaranteed } \\
\text { prompt detection of fraud in } \\
\text { this bank }\end{array}$ & -.518 & .077 & -.407 & -6.753 & .000 & -.281 & -.442 & -.375 & .846 & 1.183 \\
\hline & $\begin{array}{l}\text { Forensic audit guarantees the } \\
\text { safety of this bank's assets } \\
\text { from unauthorized usage }\end{array}$ & -.290 & .083 & -.228 & -3.501 & .001 & .155 & -.247 & -.194 & .725 & 1.380 \\
\hline & $\begin{array}{l}\text { Forensic audit ensures } \\
\text { efficient segregation of duties } \\
\text { in this bank to forestall fraud }\end{array}$ & .826 & .079 & .650 & 10.472 & .000 & .525 & .607 & .581 & .799 & 1.251 \\
\hline
\end{tabular}

Note: a. Dependent variable: Control of financial fraud in DMBs. 
Table 5. Collinearity diagnostics ${ }^{\mathrm{a}}$

\begin{tabular}{|c|c|c|c|c|c|c|c|c|}
\hline \multirow[b]{2}{*}{ Model } & \multirow[b]{2}{*}{ Dimension } & \multirow[b]{2}{*}{ Eigenvalue } & \multirow[b]{2}{*}{$\begin{array}{l}\text { Condition } \\
\text { index }\end{array}$} & \multicolumn{5}{|c|}{ Variance proportions } \\
\hline & & & & Constant & $\begin{array}{l}\text { The practice } \\
\text { of forensic } \\
\text { accounting } \\
\text { helps } \\
\text { mitigate } \\
\text { financial } \\
\text { fraud in this } \\
\text { bank }\end{array}$ & $\begin{array}{c}\text { Forensic } \\
\text { audit } \\
\text { guaranteed } \\
\text { prompt } \\
\text { detection of } \\
\text { fraud in this } \\
\text { bank }\end{array}$ & $\begin{array}{c}\text { Forensic } \\
\text { audit } \\
\text { guarantees } \\
\text { the safety of } \\
\text { this bank's } \\
\text { assets from } \\
\text { unauthorized } \\
\text { usage }\end{array}$ & $\begin{array}{c}\text { Forensic } \\
\text { audit ensures } \\
\text { efficient } \\
\text { segregation } \\
\text { of duties in } \\
\text { this bank to } \\
\text { forestall fraud }\end{array}$ \\
\hline \multirow{5}{*}{1} & 1 & 4.962 & 1.000 & .00 & .00 & .00 & .00 & .00 \\
\hline & 2 & .017 & 16.860 & .00 & .07 & .22 & .21 & .06 \\
\hline & 3 & .011 & 20.804 & .00 & .57 & .23 & .01 & .13 \\
\hline & 4 & .007 & 27.616 & .02 & .13 & .12 & .35 & .81 \\
\hline & 5 & .002 & 46.255 & .98 & .22 & .42 & .43 & .00 \\
\hline
\end{tabular}

Note: a. Dependent variable: Control of financial fraud in DMBs.

considered problematic, and all the VIFs in Table 4 are not greater than 10. Also, Myers (1990) posited that a variance inflation factor (VIF) of more than 10 calls for alarm, but in this study, VIFs are less than 10 .

Table 5 allows us to confirm that there is no serious challenge with multicollinearity. This is because many of the eigenvalues are close to 0 , which indicates high inter-correlation among predictors. It shows that small changes in the data values may lead to large changes in coefficient estimates. The condition indices are computed as the square roots of the ratios of the largest eigenvalue to each successive eigenvalue. Values greater than 15 indicate potential problems with collinearity, greater than 30, a serious problem. Four of these indices are less than 30 , suggesting no serious problem with collinearity.

Further analysis of hypothesis one using correlation confirms that forensic auditing has a significant effect on the control of financial frauds in the Deposit Money Banks in Nigeria (see Table 6). Table 6 shows a 51\% correlation between variables, and the result is also significant at the 0.05 level, so the alternative hypothesis $H 1$ is accepted. This result is in line with the submissions of Islam, Rahman and Hossan (2011), Enofe, Omagbon, and Ehigiator (2015), Enofe, Okpako, and Atube (2013), Onuorah and Ebimobowei (2012), Dada, Owolabi, and Okwu (2013) and Modugu and Anyanduba (2013) that forensic audit is vital to the amelioration of financial frauds in any corporate organization or institution.

\subsection{Hypothesis two}

$\mathrm{H}_{2}$ : There is no significant effect between the forensic auditor's skills and knowledge and timely adjudication of financial fraud cases in the DMBs in Nigeria.

Tables 7 and 8 reveal that while the correlation (R) between the independent variables and the dependent variable was 0.534 , the estimated ad-

Table 6. Correlations

\begin{tabular}{|c|c|c|c|}
\hline Construct & & $\begin{array}{l}\text { Fraud examination helps build } \\
\text { an efficient internal control } \\
\text { system to forestall fraud } \\
\text { incidents in this bank }\end{array}$ & $\begin{array}{c}\text { Forensic audit } \\
\text { guarantees the safety of } \\
\text { this bank's assets from } \\
\text { unauthorized usage }\end{array}$ \\
\hline \multirow{3}{*}{$\begin{array}{l}\text { Fraud examination helps build an efficient } \\
\text { internal control system to forestall fraud } \\
\text { incidents in this bank }\end{array}$} & Pearson correlation & 1 & $.514 * *$ \\
\hline & Sig. (2-tailed) & - & .000 \\
\hline & $N$ & 193 & 193 \\
\hline \multirow{3}{*}{$\begin{array}{l}\text { Forensic audit guarantees the safety of this } \\
\text { bank's assets from unauthorized usage }\end{array}$} & Pearson correlation & $.514^{* *}$ & 1 \\
\hline & Sig. (2-tailed) & .000 & - \\
\hline & $N$ & 193 & 193 \\
\hline
\end{tabular}

Note: ${ }^{* *}$ Correlation is significant at the 0.01 level (2-tailed). 
Table 7. Model summary

\begin{tabular}{c|c|c|c|c|c|c|c|c}
\hline Model & $\mathbf{R}$ & $\begin{array}{c}\mathbf{R} \\
\text { square }\end{array}$ & $\begin{array}{c}\text { Adjusted } \\
\text { R-squared }\end{array}$ & $\begin{array}{c}\text { Std. error of } \\
\text { the estimate }\end{array}$ & \multicolumn{5}{|c}{ Change statistics } \\
\hline 1 & $.534 a$ & .285 & .270 & .54447 & .285 & 18.727 & 4 & 188 \\
\hline
\end{tabular}

Note: a. Predictors: (constant). Forensic auditors combat fraudulent activities headlong to ensure sanity in this bank. Forensic auditor has assisted this bank's lawyers in executing their legal assignments by providing necessary information. Forensic auditor is assisting this bank in reducing the occurrence of fraud cases. Forensic auditor, being an expert in legal matters, has helped this bank in improving its operational manual for seamless operation.

Table 8. ANOVA

\begin{tabular}{|c|c|c|c|c|c|c|}
\hline & Model & Sum of squares & df & Mean square & $\mathbf{F}$ & Sig. \\
\hline \multirow{3}{*}{1} & Regression & 22.206 & 4 & 5.552 & 18.727 & $.000^{\mathrm{b}}$ \\
\hline & Residual & 55.732 & 188 & .296 & - & - \\
\hline & Total & 77.938 & 192 & - & - & - \\
\hline
\end{tabular}

Note: a. Dependent variable: Control of financial fraud in DMBs; b. Predictors: (constant) Forensic auditors combat fraudulent activities headlong to ensure sanity in this bank. Forensic auditor has assisted this bank's lawyers in executing their legal assignments by providing necessary information. Forensic auditor is assisting this bank in reducing the occurrence of fraud cases. Forensic auditor, being an expert in legal matters, has helped this bank in improving its operational manual for seamless operation.

justed R-squared was 0.27 . This implies that independent variables when taking together accounted for 27.0 percent of timely adjudication of financial fraud cases in DMBs. Further verification using Regression ANOVA revealed that forensic auditor's skills and knowledge had a significant effect on timely adjudication of fraud cases in Nigeria. Evidence given in Tables 7 and 8, based on hypothesis tested above, showed that calculated $r(0.270)$ and $F$ (18.727) were greater than the tabulated $r$ (0.195) and $F$ (2.372), given 190 degree of freedom at the 0.05 level of significance, thus rejecting the null hypothesis which states that there is no significant effect between the forensic auditor's skills and knowledge and timely adjudication of financial fraud cases in the DMBs in Nigeria.

To determine the relative importance of the significant predictors, Table 9 shows standardized coefficients. Although forensic auditors have a negative or lowest coefficient in the area of improvement in the operational manual to detect fraud,

Table 9. Coefficients ${ }^{\mathrm{a}}$

\begin{tabular}{|c|c|c|c|c|c|c|c|c|c|c|c|}
\hline & \multirow{2}{*}{ Model } & \multicolumn{2}{|c|}{$\begin{array}{c}\text { Unstandardized } \\
\text { coefficients }\end{array}$} & \multirow{2}{*}{$\begin{array}{c}\text { Standardized } \\
\text { coefficients } \\
\text { Beta }\end{array}$} & \multirow{2}{*}{$\mathbf{t}$} & \multirow{2}{*}{ Sig. } & \multicolumn{3}{|c|}{ Correlations } & \multicolumn{2}{|c|}{$\begin{array}{c}\text { Collinearity } \\
\text { statistics }\end{array}$} \\
\hline & & B & $\begin{array}{l}\text { Std. } \\
\text { error }\end{array}$ & & & & $\begin{array}{l}\text { Zero- } \\
\text { order }\end{array}$ & Partial & Part & Tolerance & VIF \\
\hline \multirow{5}{*}{1} & Constant & 5.379 & .670 & & 8.026 & .000 & & & & & \\
\hline & $\begin{array}{l}\text { Forensic auditor is assisting this } \\
\text { bank in reducing the occurrence } \\
\text { of fraud cases }\end{array}$ & .640 & .083 & .504 & 7.756 & .000 & .469 & .492 & .478 & .901 & 1.109 \\
\hline & $\begin{array}{l}\text { Forensic auditor has assisted this } \\
\text { bank's lawyers in executing their } \\
\text { legal assignments by providing } \\
\text { necessary information }\end{array}$ & .341 & .139 & .328 & 2.448 & .015 & -.052 & .176 & .151 & .212 & 4.708 \\
\hline & $\begin{array}{l}\text { Forensic auditor, being an expert } \\
\text { in legal matters, has helped this } \\
\text { bank in improving its operational } \\
\text { manual for seamless operation }\end{array}$ & -.323 & .127 & -.345 & -2.535 & .012 & -.159 & -.182 & -.156 & .206 & 4.863 \\
\hline & $\begin{array}{l}\text { Forensic auditors combat } \\
\text { fraudulent activities headlong to } \\
\text { ensure sanity in this bank }\end{array}$ & .172 & .088 & .135 & 1.954 & .052 & .078 & .141 & .121 & .794 & 1.259 \\
\hline
\end{tabular}

Note: a. Dependent variable: Control of financial fraud in DMBs. 
Table 10. Collinearity diagnostics ${ }^{a}$

\begin{tabular}{|c|c|c|c|c|c|c|c|c|}
\hline \multirow[b]{2}{*}{ Model } & \multirow[b]{2}{*}{ Dimension } & \multirow[b]{2}{*}{ Eigenvalue } & \multirow[b]{2}{*}{$\begin{array}{l}\text { Condition } \\
\text { Index }\end{array}$} & \multicolumn{5}{|c|}{ Variance proportions } \\
\hline & & & & Constant & $\begin{array}{c}\text { Forensic } \\
\text { auditor is } \\
\text { assisting } \\
\text { this bank } \\
\text { in reducing } \\
\text { the } \\
\text { occurrence } \\
\text { of fraud } \\
\text { cases }\end{array}$ & \begin{tabular}{|} 
Forensic auditor \\
has assisted this \\
bank's lawyers \\
in executing \\
their legal \\
assignments \\
by providing \\
necessary \\
information
\end{tabular} & $\begin{array}{l}\text { Forensic auditor, } \\
\text { being an expert } \\
\text { in legal matters, } \\
\text { has helped } \\
\text { this bank in } \\
\text { improving its } \\
\text { operational } \\
\text { manual for } \\
\text { seamless } \\
\text { operation }\end{array}$ & $\begin{array}{l}\text { Forensic } \\
\text { auditors } \\
\text { combat } \\
\text { fraudulent } \\
\text { activities } \\
\text { headlong } \\
\text { to ensure } \\
\text { sanity in } \\
\text { this bank }\end{array}$ \\
\hline \multirow{5}{*}{1} & 1 & 4.93 & 1.000 & .00 & .00 & .00 & .00 & .00 \\
\hline & 2 & .048 & 10.098 & .01 & .04 & .03 & .07 & .03 \\
\hline & 3 & .015 & 17.844 & .00 & .32 & .01 & .01 & .31 \\
\hline & 4 & .004 & 34.015 & .09 & .12 & .82 & .62 & .01 \\
\hline & 5 & .002 & 46.247 & .90 & .51 & .14 & .30 & .65 \\
\hline
\end{tabular}

Note: a. Dependent variable: Control of financial fraud in DMBs.

they make a significant contribution to reducing the level of financial fraud, which are pivotal in the timely execution of fraud cases in the law courts by providing necessary information to the bank counsels, and play vital role in combating fraudulent practices headlong in ensuring sanity in the DMBs. For most predictors, the values of the partial and part correlations increase sharply from the zero-order correlation. This means, for example, that much of the variance in ensuring timely adjudication of fraud cases in DMBs has been explained by a forensic audit. The tolerance is the percentage of the variance in a given predictor that cannot be explained by other predictors. Thus, the small tolerances show that $20 \%$ $90 \%$ of the variance in a given predictor can be explained by other predictors. When the tolerances are close to 0 , high multicollinearity is observed and the standard error of the regression coefficients will be inflated. A variance inflation factor greater than 10 is usually considered problematic, and all the VIFs in Table 14 are not greater than 10 .

As Table 10 shows, it is possible to confirm that there is no serious challenge with multicollinearity. This is due to the fact that many of the eigenvalues are close to 0 , which indicates high inter-correlation among predictors. It shows that small changes in the data values may lead to large changes in the estimates of the coefficients. The condition indices are computed as the square roots of the ratios of the largest eigenvalue to each successive eigenvalue. Values greater than 15 indicate potential problems with collinearity, greater than 30 , which is a serious problem. So, $60 \%$ of these indices are less than 30 , suggesting no serious problem with collinearity.

Table 11. Correlations

\begin{tabular}{|c|c|c|c|}
\hline \multicolumn{2}{|l|}{ Construct } & $\begin{array}{c}\text { Forensic auditor has assisted this } \\
\text { bank's lawyers in executing their } \\
\text { legal assignments by providing } \\
\text { necessary information }\end{array}$ & $\begin{array}{l}\text { Forensic auditor being an expert } \\
\text { in legal matters has helped this } \\
\text { bank in improving its operational } \\
\text { manual for seamless operation }\end{array}$ \\
\hline \multirow{3}{*}{$\begin{array}{l}\text { Forensic auditor has assisted } \\
\text { this bank's lawyers in executing } \\
\text { their legal assignments } \\
\text { by providing necessary } \\
\text { information }\end{array}$} & $\begin{array}{l}\text { Pearson } \\
\text { Correlation }\end{array}$ & 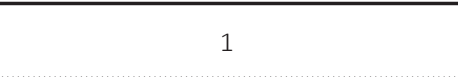 & $.870^{* *}$ \\
\hline & Sig. (2-tailed) & - & .000 \\
\hline & $\mathrm{N}$ & 193 & 193 \\
\hline \multirow{3}{*}{$\begin{array}{l}\text { Forensic auditor being an } \\
\text { expert in legal matters has } \\
\text { helped this bank in improving } \\
\text { its operational manual for } \\
\text { seamless operation. }\end{array}$} & $\begin{array}{l}\text { Pearson } \\
\text { Correlation }\end{array}$ & $.870^{* *}$ & 1 \\
\hline & Sig. (2-tailed) & .000 & - \\
\hline & $\mathrm{N}$ & 193 & 193 \\
\hline
\end{tabular}

Note: $* *$ Correlation is significant at the 0.01 level (2-tailed). 
Table 11 shows $87 \%$ correlation, which depicts a significant association between the forensic auditor's skills and knowledge and timely adjudication of financial fraud cases in the DMBs in Nigeria. The hypothesis is positive at the $5 \%$ level of significance, since it is greater than 0.05 or $5 \%$. This shows that there is conclusive evidence of the significant association between the variables. These results are in line with the submissions of Adeniyi (2016) and Owolabi, Dada, and Olaoye (2013) that forensic auditors have been instrumental to timely execution of bank's fraudulent financial cases in the law court in Nigeria.

\subsection{Hypothesis three}

H3: The experience of a forensic auditor has no significant effect on fraud control in the $D M B s$ in Nigeria.

Table 12 shows that fraud control is more significant or evident when forensic auditors have over 10-year experience with a mean of 9.5116, followed by auditors with experience of 5 to 10 years, and lastly, experience between 1 and 5 years with mean values of 9.1625 and 8.9 , respectively. This result is significant, because the more experienced a forensic auditor, the more effective and efficient he would be in detecting and combating financial frauds.

Table 13 shows that a calculated F-value of 13.993 resulted from the experience of a forensic auditor in fraud control in the DMBs in Nigeria. This calculated F-value of 13.993 is significant, since it is greater than the critical F-value of 3.995, given 2 and 190 degrees of freedom at the 5\% level of significance. Consequently, the null hypothesis was rejected.

It can, therefore, be concluded that while forensic auditors with experience of 1 to 5 years had weak but significant effect on fraud control, forensic auditors with more than 10-year experience had a strong and significant effect on fraud control, and finally, forensic auditors with experience of 5 to 10 years had a moderate but significant effect on fraud control. In summary, the result shows that the experience of a forensic auditor has a

Table 12. Descriptive statistics

\begin{tabular}{|c|c|c|c|c|c|c|c|c|c|c|}
\hline \multirow{2}{*}{\multicolumn{2}{|c|}{ Variables }} & \multirow{2}{*}{$\mathbf{N}$} & \multirow{2}{*}{ Mean } & \multirow{2}{*}{$\begin{array}{c}\text { Std. } \\
\text { deviation }\end{array}$} & \multirow{2}{*}{$\begin{array}{l}\text { Std. } \\
\text { error }\end{array}$} & \multicolumn{2}{|c|}{$\begin{array}{l}95 \% \text { confidence } \\
\text { interval for mean }\end{array}$} & \multirow{2}{*}{ Minimum } & \multirow{2}{*}{ Maximum } & \multirow{2}{*}{$\begin{array}{c}\text { Between- } \\
\text { component } \\
\text { variance }\end{array}$} \\
\hline & & & & & & $\begin{array}{l}\text { Lower } \\
\text { bound }\end{array}$ & $\begin{array}{l}\text { Upper } \\
\text { bound }\end{array}$ & & & \\
\hline \multicolumn{2}{|c|}{$1-5$ years } & 70 & 8.9000 & .68419 & .08178 & 8.7369 & 9.0631 & 8.00 & 10.00 & - \\
\hline \multicolumn{2}{|c|}{$5-10$ years } & 80 & 9.1625 & .56128 & .06275 & 9.0376 & 9.2874 & 8.00 & 10.00 & - \\
\hline \multicolumn{2}{|c|}{10 years and above } & 43 & 9.5116 & .50578 & .07713 & 9.3560 & 9.6673 & 9.00 & 10.00 & - \\
\hline \multicolumn{2}{|l|}{ Total } & 193 & 9.1451 & .63712 & .04586 & 9.0546 & 9.2355 & 8.00 & 10.00 & - \\
\hline \multirow{2}{*}{ Model } & $\begin{array}{l}\text { Fixed } \\
\text { effects }\end{array}$ & - & - & .59794 & .04304 & 9.0602 & 9.2300 & - & - & - \\
\hline & $\begin{array}{l}\text { Random } \\
\text { effects }\end{array}$ & - & - & - & .16768 & 8.4236 & 9.8666 & - & - & .07441 \\
\hline
\end{tabular}

Table 13. ANOVA

\begin{tabular}{|c|c|c|c|c|c|}
\hline \multicolumn{6}{|c|}{ Control of financial fraud in DMBs } \\
\hline Constructs & Sum of squares & Df & Mean square & $\mathbf{F}$ & Sig. \\
\hline Between groups & 10.006 & 2 & 5.003 & 13.993 & .000 \\
\hline Within groups & 67.932 & 190 & .358 & & \\
\hline Total & 77.938 & 192 & & & \\
\hline
\end{tabular}


Table 14. Gender of a forensic auditor

\begin{tabular}{l|c|c|c|c|c|c|c}
\hline \multicolumn{1}{c|}{ Variables } & $\mathbf{N}$ & $\bar{X}$ & SD & df & t-cal. & r-cit. & Decision \\
\hline Male & 120 & 7.8167 & .89802 & 191 & 0.760 & 1.96 & Not significant \\
\hline Female & 73 & 7.9178 & .89370 & & & & \\
\hline
\end{tabular}

Note: $P \leq 0.05$ level of significance.

significant effect on fraud control in the DMBs in Nigeria. This result is in line with those of Okoye and Gbegi (2013), Modugu and Anyaduba (2013), Enofe, Utomwen, and Danjuma (2015), and Okafor and Agbiogwu (2016) where the need for experience is emphasized.

\subsection{Hypothesis four}

H4: The gender of a forensic auditor has no significant effect on his/her expert report for timely execution of financial fraud cases in the law court in Nigeria.

T-test is used to investigate the effect of gender of a forensic auditor on timely execution of financial fraud cases in the law court. Table 14 shows that gender has no influence on the effectiveness of a forensic auditor's expert report. This is evident in the $\mathrm{t}$-cal. of .760, which is less than r-cit. of 1.96 and not significant at the $5 \%$ level of significance.
This, therefore, leads to a coincidence with null hypothesis.

\subsection{Result summary}

Table 15. Analysis of null hypotheses

Source: Compiled by authors (2018)

\begin{tabular}{|c|c|c|}
\hline Null hypotheses & Accept & Reject \\
\hline $\begin{array}{l}\text { H1: Forensic audit has no significant } \\
\text { effect on the control of financial frauds in } \\
\text { the DMBs in Nigeria }\end{array}$ & & $\checkmark$ \\
\hline $\begin{array}{l}\text { H2: There is no significant association } \\
\text { between the forensic auditor's skills } \\
\text { and knowledge and timely adjudication } \\
\text { of financial fraud cases in the DMBs in } \\
\text { Nigeria }\end{array}$ & & $\checkmark$ \\
\hline $\begin{array}{l}\text { H3: The experience of a forensic auditor } \\
\text { has no significant effect on fraud control } \\
\text { in the DMBs in Nigeria }\end{array}$ & & $\checkmark$ \\
\hline $\begin{array}{l}\text { H4: The gender of a forensic auditor has } \\
\text { no significant effect on his/her expert } \\
\text { report for timely execution of financial } \\
\text { fraud cases in the law court in Nigeria }\end{array}$ & $\checkmark$ & \\
\hline
\end{tabular}

\section{CONCLUSION AND RECOMMENDATIONS}

This study focused on forensic audit as a tool for fraud control in Deposit Money Banks (DMBs) in Nigeria. In an attempt to unravel the objectives of the study, four hypotheses were developed and tested, which include the role of forensic auditing in controlling financial frauds in DMBs, the relevance of a forensic auditor's skills and knowledge in providing a quality expert opinion for the timely adjudication of financial fraud cases in courts of law, the degree to which the experience of a forensic auditor is related to reduction or detection of financial frauds in DMBs, and the effect of gender on the timely resolution of court cases.

This study has established that forensic audit is an indispensable prerequisite for effective and efficient control of financial frauds in the Nigerian Deposit Money Banks (DMBs). According to 2014 ACFE reports, fraud has been hatched for an average of eighteen months before being released, which has serious implications for the bank's continuous operation. Therefore, given the findings, the application of forensic auditing principles will serve as a panacea for early detection and prevention of frauds not only in financial institutions such as DMBs, but also in any other business enterprises. Consequently, fraudulent and sharp practices in the banks will be ameliorated if a forensic auditor is involved.

The study recommends that the banking sector regulators insist on adopting a law that would make it mandatory to establish a forensic audit unit in all licensed commercial banks operating in the country. This will also enhance their oversight functions, which will strengthen confidence in the safety of the 
depositors' funds. Designing and implementing an effective and efficient forensic audit department are pivotal to fraud prevention. Forensic audit units should ensure that all employees, regardless of status, comply with bank policies through effective control and monitoring mechanisms. Any deviations from the established rules should be immediately reported to management. Forensic auditors can help strengthen policies of DMBs by providing necessary controls, especially in the area of information technology, to prevent frauds.

As a result of this study, a 'fraud root theory' was developed, which explains what motivates an individual to fraud, especially in the continent of Africa. This is based on the fact that a person's motivation in Europe or America may differ from what motivates a person in Nigeria, which is termed as environmental factors. Four main motives were identified, such as poverty; porous legal system; custom, culture and tradition; and penchant for and holding on to power. If these factors are efficiently and effectively managed, the incidences of fraud will be reduced to the minimum.

This research can be improved by comparing the prevalence of frauds in banks with other financial institutions in Nigeria, especially in the insurance sector. Further research can also be undertaken by examining the key factors responsible for financial frauds in Nigeria compared to their counterparts in other African countries. Again, further research might consider the accuracy and adequacy of the legal system in combating financial fraud in Nigeria, both in private and public institutions.

\section{REFERENCES}

1. Abiola, I., \& Oyewole, A. T. (2013). The internal control system on fraud detection: Nigeria Experience. Journal of Accounting and Finance, 13(5), 141-152. Retrieved from http://digitalcommons.www.na-businesspress.com/ JAF/AbiolaI_Web13_5_.pdf

2. Adeniyi, A. A. (2016). Forensic auditing and financial fraud in Nigerian Deposit Money Banks (DMBs). European Centre for Research Training and Development, 4(8), 1-19. Retrieved from http://www.eajournals.org/ wp-content/uploads/ForensicAuditing-and-Financial-Fraud-inNigerian-Deposit-Money-BanksDMBS.pdf

3. Akenbor, C. O., \& Ironkwe, U. (2014). Forensic auditing techniques and fraudulent practices of public institutions in Nigeria. Journal of Modern Accounting and Auditing, 10(4), 451-459. Retrieved from https://www.researchgate.net/ publication/275712337_Forensic_Auditing_Techniques_and_ Fraudulent_Practices_of_Public_Institutions_in_Nigeria

4. Albrecht, W. S., Hill, N. C., \& Albrecht, C. C. (2006). The ethics development model applied to declining ethics in accounting. Australian Accounting Review, 16(1), 30-40. https://doi. org/10.1111/j.1835-2561.2006. tb00323.x

5. American Institute of Certified Public Accountants (AICPA). (2008). Considerations of fraud in a financial statement audit. Statement on Auditing Standard (SAS) No. 99, 1719-1770. Retrieved from https://www.aicpa. org/Research/Standards/AuditAttest/DownloadableDocuments/ AU-00316.pdf

6. Association of Certified Fraud Examiners (ACFE). (2014). Report to the nations on occupational fraud and abuse. Retrieved from https://www.acfe.com/rttn-summary.aspx

7. Bhasin, M. (2007). Forensic accounting: A new paradigm for niche consulting. The Chartered Accountant, 1000-1010. Retrieved from https://papers.ssrn.com/sol3/ papers.cfm?abstract_id $=2703647$

8. Chui, L., \& Pike, B. (2013). Auditors' responsibility for fraud detection: New wine in old bottles? Journal of Forensic \& Investigative Accounting, 5(1), 204-
233. Retrieved from https://pdfs. semanticscholar.org/35d8/1a9ab 602e90bdbbc93440d8d2ca7b43f bc3e.pdf

9. Crumbley, D. L. (2001). Forensic accounting: Older than you think. Journal of Forensic Accounting, 11(2), 181-202. Retrieved from https://www.researchgate.net/publication/238659496_Forensic_Accounting_Older_Than_You_Think

10. Dada, S. O., Owolabi, S. A., \& Okwu, A. T. (2013). Forensic accounting a panacea to alleviation of fraudulent practices in Nigeria. International Journal of Business, Management and Economics Research, 4(5), 787-792. Retrieved from http://www.ijbmer. com/docs/volumes/vol4issue5/ ijbmer2013040503.pdf

11. Dandago, K. I. (1997). Fraud detection and control at the local government level. Journal of the Association of National Accountant of Nigeria, 7(4),45-58.

12. Degboro, D., \& Olofinsola, J. (2007). Forensic accountants and the litigation support engagement. Nigerian Accountant, 40(2), 49-52.

13. Dhar, P., \& Sarkar, A. (2010). Forensic accounting: An 
Accountant's Vision. Vidyasagar University Journal of Commerce, 15(3), 93-104. Retrieved from https://pdfs.semanticscholar.or g/3f26/337b3959dffb766a7464 410de67b86398329.pdf?_ga =2.22984243.929263868.1585807898-2100778558.1584432533

14. Efiong, E. (2012). Forensic accounting education: An exploration of level of awareness in developing economies Nigeria as a case study. International Journal of Business and Management, 7(4), 26-34. https://doi.org/10.5539/ijbm. v7n4p26

15. Elias, A. I. (2014). The use of forensic in fraud detection and control. International Journal of Research in Management, 4(5), 61-71.

16. Emeh, Y., \& Obi, J. O. (2013). An empirical analysis of forensic accounting and financial fraud in Nigeria. African Journal of Social Sciences, 3(4), 112-121.

17. Enofe, A. O., Okpako, P. O., \& Atube, E. N. (2013). The impact of forensic accounting on fraud detection. European Journal of Business and Management, 5(26), 61-72. Retrieved from https:// www.iiste.org/Journals/index.php/ EJBM/article/view/8063/8602

18. Enofe, A. O., Omagbon, P., \& Ehigiator, F. I. (2015). Forensic audit and corporate fraud. International Journal of Economics and Business Management, 1(7), 1-11. Retrieved from https:// iiardpub.org/get/IJEBM/VOL\%20 1/55-64.pdf

19. Enofe, A. O., Utomwen, O. A., \& Danjuma, E. J. (2015). The role of forensic accounting in mitigating financial crimes. International Journal of Advanced Academic Research - Social Sciences and Education, 2(12), 1-25. Retrieved from https://ijaar.org/articles/ volume1-Number2/The_Role_Of Forensic_Accounting_In_Mitigating_Financial_Crimes.pdf

20. Erin, O., Ogundele, O., \& Ogundele, I. (2016).

Whistleblowing and quality of financial reporting in the Nigerian Banking Sector. $3^{\text {rd }}$ International
Conference on African

Development Issues (pp. 103-107).

Retrieved from http://eprints. covenantuniversity.edu.ng/6640/1/ icadi16pp103-107.pdf

21. Eyisi, A. S, \& Agbaeze, E. K (2014) The impact of forensic auditors in corporate governance. International Journal of Development and Sustainability, 3(2), 404-417. Retrieved from https://isdsnet.com/ ijds-v3n2-14.pdf

22. Fox, W., \& Bayat, M. S. (2007). A Guide to Managing Research. Cape Town: Juta Publications.

23. George B. (2007). Forensic Accounting. RT Edward Inc., USA.

24. Gray, O. R., \& Moussalli, S. D. (2006). Forensic accounting and auditing united again: A historical perspective. Journal of Business Issues, 4(2), 15-25. Retrieved from https://papers.ssrn.com/sol3/papers.cfm?abstract_id $=1642100$

25. Islam, J., Rahman, H., \& Hossan, M. (2011). Forensic accounting as a tool for detecting fraud and corruption: An empirical study in Bangladesh. ASA University Review, 5(2), 77-85. Retrieved from https://www.semanticscholar org/paper/Forensic-Accountingas-a-Tool-for-Detecting-FraudIslam-Rahman/593e7f917fcc37842 08ecd08d1fcddb08313066d

26. Madray, J. R. (2006). New Fraud Guidance. Journal of Accountancy, 51-55. Retrieved from https:// www.journalofaccountancy.com/ issues/2006/jan/newfraudguidance.html

27. Modugu, K. P., \& Anyaduba, J. O. (2013). Forensic accounting and financial fraud in Nigeria: An empirical approach. International Journal of Business and Social Science, 4(7), 23-42. Retrieved from http://ijbssnet.com/journals/Vol_4_No_8_Special_Issue_July_2013/28.pdf

28. Mukuro, D., Yamusa, O., \& Faboyede, S. (2013). The role of forensic accountants in fraud detection and national security in Nigeria. Change and Leadership, 17(2), 90-106. Retrieved from https://pdfs.semanticscholar.org/ eaef/2e1b5789943588a29db8cf8 1a3c40e4ca519.pdf?_ga $=2.266$ 320391.929263868.1585807898-2100778558.1584432533

29. Myers, R. H. (1990). Classical and modern regression with applications (2nd ed.). PWS Kent, Boston, MA. Retrieved from https://lib.ugent.be/catalog/ rug01:000851135

30. Njanike, K, Dube, T., \& Mashayanye, E. (2009). The effectiveness of forensic auditing in detecting, investigating, and preventing bank frauds. Journal of Sustainable Development in Africa, 10(4), 405-425. Retrieved from http://ir.buse.ac.zw/xmlui/ handle/11196/453

31. Ogutu, J. O., \& Ngahu, S. (2016). Application of forensic auditing skills in fraud mitigation: $\mathrm{A}$ survey of accounting firms in the County Government of Nakuru, Kenya. Journal of Business and Management, 4(18), 73-79. Retrieved from https:// www.academia.edu/25162195/ Application_of_Forensic_Auditing_Skills_in_Fraud_ Mitigation_A_Survey_of_Accounting_Firms_In_The_County_ Government_of_Nakuru_Kenya

32. Okafor, M. C., \& Agbiogwu, A. A. (2016). Effects of forensic accounting skills on the management of bank fraud in Nigeria. European Centre for Research Training and Development, 4(6), 70-80. Retrieved from http://www.eajournals.org/wp-content/uploads/ Effects-of-Forensic-AccountingSkills-on-the-Management-ofBank-Fraud-in-Nigeria.pdf

33. Okoye, E. I., \& Gbegi, D. O. (2013). Forensic accounting: A tool for fraud detection and prevention in the public sector: A study of selected ministries in Kogi State. International Journal of Academic Research in Business and Social Sciences, 3(3), 1-19. Retrieved from http://hrmars.com/admin/ pics/1671.pdf

34. Okunbor, J. A., \& Obaretin, O. (2010). Effectiveness of the application of forensic accounting services in Nigerian organizations. Journal of Management Sciences, 1(1), 171-184 
35. Onodi, B. E., Okafor, T. G., \& Onyali, C. I. (2015). The impact of forensic investigative methods on corporate fraud deterrence in banks in Nigeria. European Journal of Accounting, Auditing and, Finance, 3(4), 69-85. Retrieved from https://www. eajournals.org/journals/europeanjournal-of-accounting-auditingand-finance-research-ejaafr/ vol-3issue-4-april-2015/theimpact-of-forensic-investigativemethods-on-corporate-frauddeterrence-in-banks-in-nigeria/

36. Onuorah, A. C., \& Ebimobowei, A. (2012). Fraudulent activities and forensic accounting services of banks in Port Harcourt, Nigeria. Asian Journal of Business Management, 4(2), 124-129. Retrieved from https://maxwellsci. com/print/ajbm/v4-124-129.pdf

37. Owolabi, S. A., Dada, S. O., \& Olaoye, S. A. (2013). Application of forensic accounting technique in the effective investigation and detection of embezzlement to combat corruption in Nigeria. Unique Journal of Business Management Research, 1(4), 65-70.

38. Oyier, O. E. (2013). The Impact of Forensic Accounting Services in Fraud Detection and Prevention among Commercial Banks in Kenya (MBA Thesis). School of Business, University of Nairobi. Retrieved from http://erepository.uonbi.ac.ke/bitstream/handle/11295/59611/Omondi_The\%20 impact $\% 20$ of $\% 20$ forensic $\% 20$ accounting $\% 20$ services $\% 20$ on $\% 20$ fraud $\% 20$ detection $\% 20$ and $\% 20$ prevention.pdf

39. Peloubet, M. E. (1946). Forensic accounting: its place in today's Economy. Journal of Accountancy, 1(6), 458-462.

40. Rasey, M. (2009). History of Forensic Accounting.

41. Singleton, T., \& Singleton, A. (2007). Why don't we detect more fraud? Journal of Corporate Accounting and Finance, 18(4), 7-10. https://doi.org/10.1002/jcaf.20302

42. Sutherland, E. H. (1949). WhiteCollar Crime. New York, NY: Dryden Press. Retrieved from https://trove.nla.gov.au/work/1081 0834 ? q\&sort=holdings + desc\&_ $=15$ 85813267239\&versionId $=17365469$

43. Trochim, W. M. (2009). Evidence and evaluation of forensic audit. Australasian Evaluation Society International Conference. Canberra, Australia. Retrieved from https:// www.aes.asn.au/images/stories/ files/conferences/2009/documents/ William\%20Trochim.pdf

44. Uwuigbe, U. (2011). Corporate Environmental Reporting Practices: A Comparative Study of Nigerian and South African Firms (Ph.D. Thesis). Ota: Covenant University. Retrieved from http://eprints.covenantuniversity.edu.ng/706/

45. Vukadinović, P., Knežević, G., \& Mizdraković, V. (2015). The characteristics of forensic audit and differences in relation to external audit. Forensic Science, 202-205. https://doi.org/10.15308/ finiz-2015-202-205

46. Wolf, D. T., \& Hermanson, D. R. (2004). The fraud diamond: considering the four elements of fraud. The Certified Public Accountants Journal, 38-42. Retrieved from https://digitalcommons.kennesaw.edu/cgi/viewcontent .cgi article $=2546 \&$ context $=\mathrm{fa}$ cpubs

47. Zhiwei, F., Lainhart, J. W., \& Stabbs, A. (2014). Manage what is known and what is not known: $\mathrm{A}$ road map to managing enterprise fraud risk. ISACA Journal, 5, 39-49. Retrieved from http:// www.isacajournal-digital.org/ isacajournal/2014_volume_5?pm$=2 \& \mathrm{fs}=1 \& \mathrm{pg}=40 \# \mathrm{pg} 40$ 